\title{
PUBLIC HEALTH MEASURES AS AN EFFORT TO PREVENT AND CONTROL COVID-19 IN THE COMMUNITY: A LITERATURE REVIEW
}

1| Syamikar Baridwan, 2| Agus Setiawan, 3| Henny Permatasari

Email : baridwansyamikar@gmail.com

\begin{tabular}{l} 
ABSTRACT \\
\hline On March 11, 2020, WHO declared the COVID-19 outbreak a global pandemic and it becomes \\
an international concern and urged all countries to take action to detect viral infections and \\
prevent spread. This study aims to explore various public health measures as an effort to \\
prevent and control COVID-19. This study was conducted using a literature review method \\
with descriptive analysis. Articles were obtained from online databases, namely Science \\
Direct, Proquest, Sage Publication, SpringerLink and Google Scholar which were published in \\
2020. Various studies have shown that public health measures as an effort to prevent and \\
control COVID-19 include washing hands using soap or portable hand sanitizer and avoiding \\
face and mouth contact, wearing masks and avoiding close contact with sick individuals, \\
social distancing and self-quarantine, and increasing contact testing and tracing capacity. \\
The ability of community nurses is needed to provide and maximize community nursing care \\
through health promotion
\end{tabular}

ARTICLE INFO

Keywords:

Coronavirus disease 2019; Disease prevention and control; Public health measures; Community health

DOI:

10.24252/kesehatan.v13i1

\section{Pendahuluan}

Pada akhir tahun 2019, dunia dikejutkan dengan sebuah virus corona baru yang sekarang disebut COVID-19 yang kemudian diidentifikasi sebagai penyebab munculnya penyakit pernapasan akut di Wuhan, sebuah kota di provinsi Hubei, China (1). Pada Februari 2020, World Health Organization (WHO) menetapkan penyakit COVID-19 adalah singkatan dari penyakit coronavirus 2019 yang sebelumnya disebut disebut sebagai "2019 novel coronavirus" atau "2019-nCoV" (2). Sejak kemunculan di China akhir tahun 2019, virus ini menyebar dengan sangat cepat ke seluruh dunia. Terjadinya peningkatan dan penyebaran virus yang sangat cepat dengan tingkat penyebaran dan keparahan yang mengkhawatirkan sehingga WHO menyatakan bahwa wabah virus corona China dinyatakan sebagai darurat kesehatan global atau Public Health Emergency of International Concern (PHEIC) pada tanggal 30 januari 2020 dan mengumumkan COVID-19 sebagai pandemic global pada tanggal 11 Maret 2020 (3).

Hal tersebut dilakukan sebagai upaya mendorong negara-negara untuk bekerja sama sebanyak mungkin dengan mengoordinasikan personel, dana, dan sumber daya lainnya, serta membantu membujuk warga negara agar mengikuti rekomendasi kesehatan dan kebersihan (4). COVID-19 adalah penyakit baru, yang disebabkan oleh virus corona baru yang sebelumnya tidak pernah terlihat pada manusia kemudian menyebabkan gangguan pernapasan kepada para penderitanya (2). Manifestasi klinik atau gejala klinik terkait infeksi virus corona memiliki gejala yang berbeda-beda setiap orang. Presentasi klinis dari infeksi 2019-nCoV berkisar dari pneumonia yang tidak menunjukkan gejala hingga gejala yang sangat parah seperti sindrom gangguan pernapasan akut (ARDS), syok septik, dan disfungsi multiorgan, yang dapat mengakibatkan kematian (5).

Pandemi COVID-19 yang melanda berbagai negara di dunia sampai saat ini belum terkendali. Hal tersebut disebabkan jumlah kasus COVID-19 di seluruh dunia semakin meningkat dari hari ke hari. Menurut Data pantauan situasi COVID-19 dari WHO pertanggal 9 Oktober 2020 sebanyak 36.361.054 kasus terkonfirmasi positif, sebanyak 1.056.186 meninggal dunia, dan sebanyak 350.766 penambahan kasus baru hari ini (6). Semua negara saat ini menanti kehadiran vaksin untuk menangkal infeksi virus COVID-19. Vaksin dapat menjadi upaya pencegahan dengan cara memberikan pertahanan dan perlindungan dari berbagai penyakit infeksi yang berbahaya (7). Namun, sampai detik ini vaksin serta pengobatan spesifik untuk pencegahan COVID-19 masih pada tahap pengujian (8). Saat ini terdapat lebih dari 100 kandidat vaksin COVID-19 yang sedang dikembangkan, dengan beberapa di antaranya dalam tahap uji

\footnotetext{
${ }^{1}$ Program Studi Ilmu Keperawatan Peminatan Keperawatan Komunitas, Fakultas Ilmu Keperawatan, Universitas Indonesia, 
coba pada manusia (9). Pencegahan terbaik yang bisa dilakukan adalah dengan menghindari terkena virus tersebut (10). WHO telah menyatakan bahwa pendidikan, isolasi, pencegahan, pengendalian penularan, dan pengobatan orang yang terinfeksi adalah langkah penting dalam mengendalikan penyakit menular seperti COVID-19 (11). Pedoman sementara yang diterbitkan oleh WHO pada 7 Maret 2020 tentang merespon penyebaran COVID-19 di komunitas menyatakan bahwa mencegah penyebaran COVID-19 adalah melalui pengembangan mekanisme koordinasi yang tidak hanya dilakukan oleh bidang kesehatan tetapi di berbagai bidang seperti transportasi, perjalanan, perdagangan, keuangan, keamanan dan sektor lainnya yang mencakup keseluruhan masyarakat (8).

Intervensi kesehatan masyarakat merupakan strategi yang bisa dilakukan saat ini untuk membatasi penyebaran kasus dan akan terus menjadi strategi utama untuk mengurangi penularan dan mencegah penyebaran COVID-19 (8). Selain itu, dalam mencegah dan mengendalikan COVID-19, yang terpenting adalah perlu mengkomunikasikan epidemiologi dan risiko COVID-19 secara jelas, baik kepada petugas kesehatan dan masyarakat umum sehingga semua mampu menerapkan tindakan pencegahan dan pengendalian yang didasarkan pada prinsip-prinsip ilmiah yang kuat (12). Pencegahan melalui pendidikan kesehatan dari orang ke orang masih tetap menjadi salah satu pendekatan yang paling efektif dan paling murah untuk COVID-19 dalam mengendalikan pandemi global (13). Oleh karena itu, tujuan dari studi literatur tersistematis ini adalah untuk mengeksplorasi berbagai tindakan kesehatan masyarakat sebagai upaya dalam pencegahan dan pengendalian COVID-19 di Komunitas.

\section{Metode Penelitian}

Metode yang digunakan dalam penulisan artikel ini adalah studi literature, yaitu sebuah pencarian literatur dari berbagai referensi baik international maupun nasional yang dilakukan dengan menggunakan Online DataBase diantaranya Science Direct, Proquest, Sage Publication, SpringerLink dan Google Scholar. Pada tahap awal pencarian artikel jurnal diperoleh 45 artikel yang terbit pada tahun 2020 menggunakan kata kunci coronavirus disease 2019, prevention and control measures, public health measures, community health. Dari jumlah tersebut, maka diambil 12 artikel berkualitas yang memiliki kriteria penuh dalam penulisan artikel ini. Kriteria inklusi studi ini adalah artikel terbit pada tahun 2020, artikel penelitian, review artikel, dan laporan kasus yang berkaitan dengan tindakan kesehatan masyarakat dalam pencegahan dan pengendalian COVID-19 di Komunitas. Sedangkan Kriteria eksklusi adalah artikel yang tidak fulltex dan tidak berkorelasi dengan tujuan penulisan.

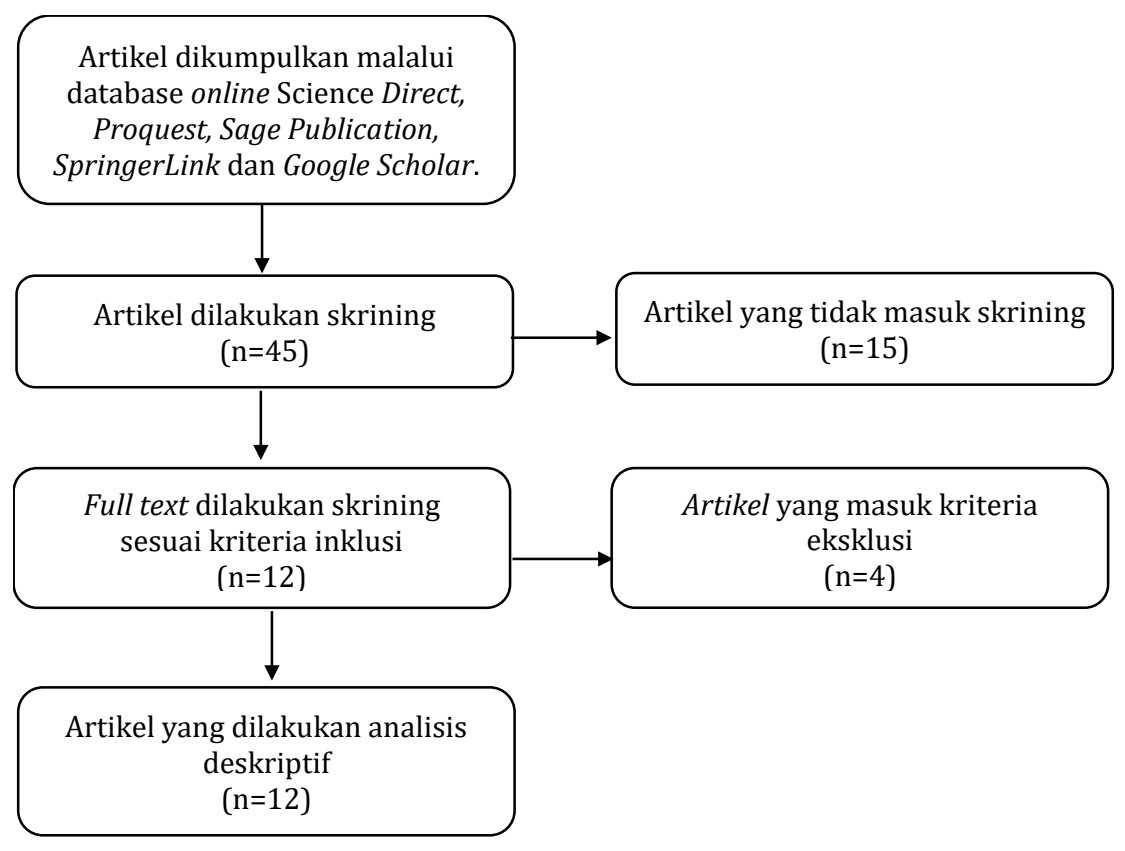

Gambar 1 Diagram pengambilan data 


\section{Hasil Penelitian}

\begin{tabular}{|c|c|c|c|c|c|}
\hline No & $\begin{array}{l}\text { Penulis/ } \\
\text { Tahun }\end{array}$ & Judul Penelitian & Tujuan Penelitian & $\begin{array}{c}\text { Metode } \\
\text { Penelitian }\end{array}$ & Hasil Penelitian \\
\hline 1 & $\begin{array}{l}\text { Güner et al., } \\
(2020)\end{array}$ & $\begin{array}{l}\text { COVID-19: } \\
\text { Prevention and } \\
\text { control measures in } \\
\text { community }\end{array}$ & $\begin{array}{l}\text { Menganalisis } \\
\text { intervensi yang } \\
\text { efektif untuk dimiliki } \\
\text { masyarakat dalam } \\
\text { melawan virus }\end{array}$ & Review Article & $\begin{array}{l}\text { Poin utama dalam mencegah } \\
\text { penyebaran di masyarakat adalah } \\
\text { kebersihan tangan, menjaga jarak, } \\
\text { dan karantina mandiri. Dengan } \\
\text { peningkatan kapasitas pengujian, } \\
\text { mendeteksi lebih banyak pasien } \\
\text { positif COVID-19, di masyarakat juga } \\
\text { memungkinkan pengurangan kasus } \\
\text { sekunder dengan aturan karantina } \\
\text { yang lebih ketat. }\end{array}$ \\
\hline
\end{tabular}

Penyebaran infeksi dapat
diminimalkan dengan membuat rekomendasi berikut. Diantaranya Karantina mandiri, menghindari kontak langsung dengan orang yang terinfeksi, menghindari perjalanan yang tidak penting; menjaga jarak dua meter, menghindari tempat

COVID-19:

Transmission,

2 Lotfi et al., prevention, and (2020) potential therapeutic opportunities

\section{Menyajikan}

informasi terbaru tentang penularan COVID-19, pencegahan, dan opsi terapi potensial.
Review Article keramaian, menghindari berjabat tangan, sering mencuci tangan dengan sabun dan air atau handsanitizer, terutama setelah menyentuh area permukaan umum, hindari menyentuh mata, hidung, dan mulut dengan tangan yang tidak dicuci; dan mendisinfeksi permukaan menggunakan semprotan atau tisu rumah.
Langkah-langkah yang diambil untuk melawan COVID-19 telah mengurangi risiko penularan pneumonia: (1) pengujian asam nukleat besar-besaran dan skrining ekstensif untuk kasus demam; (2) penguncian sosial dan karantina; (3) seluruh populasi menggunakan masker. perlindungan terhadap pneumonia saat melawan COVID19
Case Report

\section{Penerapam} jarak menujukkan bahwa tindakan ini paling efektif dan The effect of control strategies to reduce social mixing on Prem et al., outcomes of the (2020) COVID-19 epidemic in Wuhan, China: a modelling study
Memperkirakan efek tindakan pembatasan jarak fisik terhadap perkembangan epidemi COVID-19,
A Modelling Study memiliki potensi yang kuat untuk mengurangi penyebaran viruscorona dan pucak epidemic Covid-19 sehingga mengurangi tekanan akut pada system pelayanan kesehatan.

Cuci tangan dan penggunaan antiseptik berbahan dasar alkohol (ABHR) adalah cara paling sederhana dan efektif untuk mencegah penyebaran infeksi

Coronavirus (COVID- Memberikan bukti 19): infection control bagi semua dalam and prevention menghadapi measures

\section{Systematic} Reviews saluran pernapasan. Tindakan protektif seperti penggunaan masker, sarung tangan dan gaun oleh petugas kesehatan juga merupakan cara yang efektif untuk mengurangi penularan.

\section{Government}

Intervention, Risk

Perception, and the

6

Duan et al., Adoption of

(2020) Protective Action

Recommendations:

Evidence from the COVID-19
Meneliti hubungan antara intervensi pemerintah dari rekomendasi tindakan perlindungan (PAR) selama pandemic menunjukkan bahwa pencegahan dan pengendalian yang dilakukan pemerintah secara signifikan meningkatkan kemungkinan masyarakat mengadopsi protective action recommendations (PAR) yakni karantina mandiri, memakai masker pada ssat keluar rumah, menutupi 


\begin{tabular}{|c|c|c|c|c|c|}
\hline & & $\begin{array}{l}\text { Prevention and } \\
\text { Control Experience } \\
\text { of China }\end{array}$ & & & $\begin{array}{l}\text { mulut dengan tisu atau siku saat } \\
\text { bersin atau batuk, dan menuci } \\
\text { tangan. }\end{array}$ \\
\hline 7 & $\begin{array}{l}\text { Mayr et al., } \\
(2020)\end{array}$ & $\begin{array}{l}\text { Quarantine alone or } \\
\text { in combination with } \\
\text { other public health } \\
\text { measures to control } \\
\text { COVID-19: a rapid } \\
\text { review }\end{array}$ & $\begin{array}{l}\text { Menilai efek dari } \\
\text { tindakan karantina } \\
\text { mandiri yang } \\
\text { dirkomendasikan } \\
\text { oleh WHO }\end{array}$ & $\begin{array}{l}\text { A Rapid } \\
\text { Review }\end{array}$ & $\begin{array}{l}\text { Menunjukkan bahwa karantina } \\
\text { penting dalam mengurangi jumlah } \\
\text { orang yang terinfeksi dan jumlah } \\
\text { kematian. Hasil menunjukkan bahwa } \\
\text { karantina paling efektif, dan lebih } \\
\text { murah, jika dimulai lebih awal. } \\
\text { Menggabungkan karantina dengan } \\
\text { tindakan pencegahan dan } \\
\text { pengendalian lain mungkin memiliki } \\
\text { efek yang lebih besar daripada } \\
\text { karantina saja. }\end{array}$ \\
\hline 8 & $\begin{array}{l}\text { World } \\
\text { Health } \\
\text { Organizatio } \\
\text { n, (2020a) }\end{array}$ & $\begin{array}{l}\text { Responding to } \\
\text { community spread } \\
\text { of COVID-19 }\end{array}$ & $\begin{array}{l}\text { Memberikan } \\
\text { panduan untuk } \\
\text { menanggapi } \\
\text { penularan COVID-19 } \\
\text { oleh komunitas. }\end{array}$ & $\begin{array}{l}\text { Technical } \\
\text { Guidance }\end{array}$ & $\begin{array}{l}\text { Tindakan kesehatan masyarakat } \\
\text { dapat memperlambat penularan dan } \\
\text { penyebaran penyakit menular } \\
\text { berupa intervensi perlindungan } \\
\text { pribadi, lingkungan, pembatasan } \\
\text { jarak sosial, dan membatasi aktivitas } \\
\text { perjalanan. }\end{array}$ \\
\hline 9 & $\begin{array}{l}\text { Riiser et al., } \\
(2020)\end{array}$ & $\begin{array}{l}\text { Adolescents' health } \\
\text { literacy, health } \\
\text { protective measures, } \\
\text { and health-related } \\
\text { quality of life during } \\
\text { the Covid-19 } \\
\text { pandemic }\end{array}$ & $\begin{array}{l}\text { Mendeskripsikan } \\
\text { langkah-langkah } \\
\text { perlindungan } \\
\text { kesehatan selama } \\
\text { fase awal pandemi } \\
\text { Covid-19 di } \\
\text { Norwegia. }\end{array}$ & $\begin{array}{c}\text { Cross-Sectional } \\
\text { Study }\end{array}$ & $\begin{array}{l}\text { Tindakan pencegahan seperti } \\
\text { mencuci tangan, menjaga jarak } \\
\text { secara fisik, dan membatasi jumlah } \\
\text { kontak sosial adalah tindakan yang } \\
\text { paling sering dilaporkan. }\end{array}$ \\
\hline 10 & $\begin{array}{l}\text { Chen et al., } \\
(2020)\end{array}$ & $\begin{array}{l}\text { COVID-19 control in } \\
\text { China during mass } \\
\text { population } \\
\text { movements at New } \\
\text { Year }\end{array}$ & $\begin{array}{l}\text { Melaporkan efek dari } \\
\text { pembatasan social } \\
\text { dalam mengurangi } \\
\text { penyebaran virus }\end{array}$ & Case Report & $\begin{array}{l}\text { Jarak sosial telah efektif dalam } \\
\text { epidemi penyakit di masa lalu, } \\
\text { membatasi penularan dari manusia } \\
\text { ke manusia dan mengurangi } \\
\text { morbiditas dan mortalitas termasuk } \\
\text { tindakan yang lebih ketat seperti } \\
\text { isolasi dan karantina diterapkan } \\
\text { dalam kombinasi untuk } \\
\text { meningkatkan efektivitas. }\end{array}$ \\
\hline
\end{tabular}

\begin{tabular}{|c|c|c|c|c|c|}
\hline 11 & $\begin{array}{l}\text { Adhikari et } \\
\text { al., (2020) }\end{array}$ & $\begin{array}{l}\text { Epidemiology, } \\
\text { causes, clinical } \\
\text { manifestation and } \\
\text { diagnosis, } \\
\text { prevention and } \\
\text { control of } \\
\text { coronavirus disease } \\
\text { (COVID-19) during } \\
\text { the early outbreak } \\
\text { period: a scoping } \\
\text { review }\end{array}$ & $\begin{array}{l}\text { Memberikan bukti } \\
\text { temuan awal } \\
\text { mengenai } \\
\text { pencegahan dan } \\
\text { pengendalian COVID. } \\
-19\end{array}$ & $\begin{array}{l}\text { a scoping } \\
\text { review }\end{array}$ & $\begin{array}{l}\text { Tindakan pencegahan seperti } \\
\text { masker, praktik mencuci tangan, } \\
\text { menghindari kontak publik, deteksi } \\
\text { kasus, pelacakan kontak, dan } \\
\text { karantina merupakan upaya untuk } \\
\text { mengurangi penularan. }\end{array}$ \\
\hline 12 & $\begin{array}{l}\text { Islam et al., } \\
(2020)\end{array}$ & $\begin{array}{l}\text { Physical distancing } \\
\text { interventions and } \\
\text { incidence of } \\
\text { coronavirus disease } \\
\text { 2019: natural } \\
\text { experiment in } 149 \\
\text { countries }\end{array}$ & $\begin{array}{l}\text { Untuk mengevaluasi } \\
\text { hubungan antara } \\
\text { intervensi jarak fisik } \\
\text { dan kejadian } \\
\text { penyakit coronavirus } \\
2019 \text { (covid-19) } \\
\text { secara global }\end{array}$ & $\begin{array}{c}\text { Natural } \\
\text { experiment } \\
\text { with results } \\
\text { synthesised } \\
\text { using } \\
\text { metaanalysis }\end{array}$ & $\begin{array}{l}\text { Intervensi jarak fisik menunjukkan } \\
\text { bukti yang kuat terhadap penurunan } \\
\text { insiden Covid-19 secara global. }\end{array}$ \\
\hline
\end{tabular}

\section{Diskusi}

Tindakan pencegahan merupakan segala bentuk upaya yang dilakukan untuk membatasi penyebaran kasus serta menghindari atau mengurangi risiko, masalah, dan dampak buruk akibat pademi COVID-19 (1). Kehadiran vaksin yang aman merupakan tindakan pencegahan yang paling efektif untuk menangkal infeksi virus COVID-19 karena dapat memberikan pertahanan dan perlindungan dari berbagai penyakit infeksi yang berbahaya (7). Tetapi hingga saat ini vaksin serta pengobatan spesifik untuk pencegahan COVID-19 masih pada tahap 
pengujian (8). Sehingga pencegahan terbaik saat ini yang bisa dilakukan adalah dengan menghindari terkena virus (10). Temuan mengenai upaya-upaya pencegahan dan pengendalian COVID-19 di komunitas dirangkum dalam Tabel. Dari hasil penelusuran literature mengenai upaya pencegahan dan pengendalian COVID-19 di Komunitas ditemukan beberapa strategi yang paling penting dilakukan oleh masyarakat diantaranya adalah (1) dengan sering mencuci tangan menggunakan sabun atau pembersih tangan portabel dan menghindari kontak dengan wajah dan mulut mereka setelah berinteraksi dengan lingkungan yang mungkin tercemar; (2) Untuk mengurangi risiko penularan di masyarakat, individu harus disarankan untuk rajin menggunakan masker serta menghindari kontak dekat dengan individu yang sakit, jika memungkinkan; (3) untuk mengurangi penularan dari manusia ke manusia disarankan untuk melakukan social distancing dan self-quarantine; dan (4) tindakan pelacakan kontak serta meningkatkan kapasitas pengujian memungkinkan pengurangan kasus sekunder.

1. Mencuci tangan menggunakan sabun atau pembersih tangan portabel dan menghindari kontak dengan wajah dan mulut.

Mencuci tangan merupakan cara yang efektif untuk mencegah penularan virus corona. Menurut Cavanagh \& Wambier (2020) salah satu tindakan pencegahan yang perlu ditingkatkan selama pandemi COVID-19 adalah kebersihan tangan yang benar. Hal serupa juga dikemukakan oleh Jordan, (2020) yang menyebutkan bahwa cuci tangan dengan sabun dan penggunaan antiseptik berbahan dasar alkohol (ABHR) adalah cara paling sederhana dan efektif untuk mencegah penyebaran infeksi saluran pernapasan. Dalam sebuah artikel disebutkan bahwa COVID-19 dapat bertahan hidup pada permukaan benda dan bisa masuk ke dalam tubuh jika orang tersebut menyentuh barangyang sudah terkontaminasi mikroorganisme ini sehingga Kebersihan tangan tetap penting untuk mengurangi penyebaran COVID-19 (24). Hal tersebut diperkuat dalam sebuah review artikel yang ditulis oleh Haque, (2020) yang menyebutkan bahwa praktik kebersihan tangan mengurangi risiko tertular infeksi saluran pernapasan dan berkisar antara 6-44\% (nilai gabungan 24\% [95\% CI 6-40\%]), dengan risiko relatif 1,19\% (95\% CI 1,12-1,26\%), dan kemungkinan tertular infeksi saluran pernapasan tanpa praktik kebersihan tangan menjadi 16\% (95\% CI 11-21\%). Oleh karena itu, pemeliharaan kebersihan tangan yang tepat dianggap sebagai strategi pencegahan yang signifikan untuk mengendalikan infeksi baik di rumah sakit maupun di lingkungan masyarakat.

\section{Menggunakan masker serta menghindari kontak dekat dengan individu yang sakit.}

Tindakan protektif seperti penggunaan masker, sarung tangan dan gaun oleh petugas kesehatan juga merupakan cara yang efektif untuk mengurangi penularan COVID-19 (17). Penggunaan masker wajah di depan umum dapat berfungsi sebagai sarana pengendalian sumber untuk mengurangi penyebaran infeksi di masyarakat dengan meminimalkan ekskresi tetesan pernapasan dari individu yang terinfeksi yang belum menunjukkan gejala atau tetap asimtomatik (26). Penggunaan masker merupakan bagian dari paket komprehensif tindakan pencegahan dan pengendalian yang dapat membatasi penyebaran penyakit virus pernapasan tertentu, termasuk COVID-19 (27). Masker dapat digunakan baik untuk perlindungan orang sehat (dipakai untuk melindungi diri sendiri saat bersentuhan dengan individu yang terinfeksi) atau untuk pengendalian sumber (dipakai oleh individu yang terinfeksi untuk mencegah penularan selanjutnya) (28).

\section{Social distancing dan self-quarantine}

Tindakan kesehatan masyarakat dapat memperlambat penularan dan penyebaran penyakit menular berupa intervensi perlindungan pribadi, lingkungan, pembatasan jarak sosial, dan membatasi aktivitas perjalanan (8). Pembatasan jarak sosial dirancang untuk mengurangi interaksi antara orang-orang dalam komunitas yang lebih luas, dimana kemungkinan individu yang terinfeksi tanpa menunjukkan gejala memungkinkan menulari ke orang lain tetapi belum diidentifikasi sehingga belum terisolasi (29). Sedangkan, Karantina mandiri adalah pembatasan kegiatan atau pemisahan orang yang tidak sakit tetapi mungkin terpapar 
agen atau penyakit menular, dengan tujuan untuk memantau gejala dan memastikan deteksi dini kasus. Karantina berbeda dengan isolasi, yaitu pemisahan orang yang sakit atau terinfeksi dari orang lain untuk mencegah penyebaran infeksi atau kontaminasi (1). Dari sebuah artikel yang ditulis oleh Mayr et al., (2020) menunjukkan bahwa karantina penting dalam mengurangi jumlah orang yang terinfeksi dan jumlah kematian.

4. Meningkatan kapasitas pengujian dan pelacakan kontak

Salah satu langkah yang penting untuk dilakukan dalam melawan COVID-19 yang berefek terhadap pengurangan risiko penularan pneumonia yakni peningkatan upaya pengujian asam nukleat besar-besaran dan skrining ekstensif untuk kasus demam serta pelacakan kontak $(15,10)$. Poin penting lainnya dalam mencegah penyebaran penyakit ke seluruh masyarakat adalah dengan meningkatkan jumlah tes sehingga dengan demikian dapat menunjukkan lebih banyak kasus, melakukan isolasi mandiri, dan melakukan pelcakan yang telah melakukan kontak (1). Di Korea Selatan, pandemi COVID-19 saat ini mengharuskan pengujian terhadap sejumlah besar pasien secara massal dan gratis sebagai upaya untuk memberikan informasi mengenai penyebaran Covid-19 sehingga pemerintah dapat mengambil tindakan secara cepat dan upaya pencegahan dalam memutus mata rantai penularan (30).

\section{Kesimpulan}

COVID-19 merupakan salah satu masalah kesehatan yang penularannya dapat dicegah dan dikelola/ dikendalikan. Berdasarkan tinjauan literatur ini, didapatkan hasil bahwa tindakan kesehatan masyarakat sebagai upaya pencegahan dan pengendalian COVID-19 di Komunitas adalah mencuci tangan dengan sabun, menggunakan masker, Social distancing dan selfquarantine, serta meningkatan kapasitas pengujian dan pelacakan kontak. Tindakan ini diharapkan dapat menekan laju penularan COVID-19 di tatanan komunitas. Intervensi kesehatan masyarakat merupakan strategi yang bisa dilakukan saat ini untuk membatasi penyebaran kasus dan akan terus menjadi alat penting untuk mengurangi penularan dan mencegah penyebaran COVID-19.

\section{Daftar Pustaka}

1. Güner R, Hasanoğlu İ, Aktaş F. Covid-19: Prevention and control measures in community. Turkish J Med Sci. 2020;50(SI-1):571-7.

2. Centers For Disease Control and Prevention. About COVID-19 [Internet]. 2020. Available from: https://www.cdc.gov/coronavirus/2019-ncov/cdcresponse/about-COVID-19.html

3. WHO. WHO Director-General's opening remarks at the media briefing on COVID-19 - 11 March 2020 [Internet]. 2020 [cited 2020 Sep 29]. Available from: https://www.who.int/dg/speeches/detail/who-director-general-s-opening-remarks-atthe-media-briefing-on-covid-19---11-march-2020

4. Cucinotta D, Vanelli M. WHO declares COVID-19 a pandemic. Acta Biomed. 2020;91(1):15760.

5. Guan W, Ni Z, Hu Y, Liang W, Ou C, He J, et al. Clinical characteristics of coronavirus disease 2019 in China. N Engl J Med. 2020;382(18):1708-20.

6. WHO. WHO Coronavirus Disease (COVID-19) Dashboard (9 Oktober 2020) [Internet]. 2020. Available from: https://covid19.who.int/

7. WHO. Vaccines and immunization [Internet]. 2020. Available from: https://www.who.int/health-topics/vaccines-and-immunization\#tab=tab_1

8. WHO. Responding to community spread of COVID-19. Interim Guid 7 March [Internet]. 2020;(March):1-6. Available from: https://www.who.int/publications/i/item/respondingto-community-spread-of-covid-19

9. WHO. The push for a COVID-19 vaccine [Internet]. 2020. Available from: https://www.who.int/emergencies/diseases/novel-coronavirus-2019/covid-19-vaccines

10. Adhikari SP, Meng S, Wu Y, Mao Y, Ye R, Wang Q, et al. Novel Coronavirus during the early outbreak period: Epidemiology, causes, clinical manifestation and diagnosis, prevention 
and control. Infect Dis Poverty [Internet]. 2020;9(29):1-12. Available from: https://link.springer.com/article/10.1186/s40249-020-00646-x

11. WHO. WHO Director-General's opening remarks at the media briefing on COVID-19 - 11 March 2020 [Internet]. 2020. Available from: https://www.who.int/dg/speeches/detail/who-director-general-s-opening-remarks-atthe-media-briefing-on-covid-19---11-march-2020

12. Xiao Y, Torok ME. Taking the right measures to control COVID-19. Lancet Infect Dis [Internet]. 2020;20(5):523-4. Available from: http://dx.doi.org/10.1016/S14733099(20)30152-3

13. Dabbagh A. The role of Instagram in public health education in COVID-19 in Iran. J Clin Anesth. 2020;(January).

14. Lotfi M, Hamblin MR, Rezaei N. COVID-19: Transmission, prevention, and potential therapeutic opportunities. Clin Chim Acta. 2020;508(April):254-66.

15. Wu D, Lu J, Cao L, Ma X, Liu Q, Liu Y, et al. Positive effects of COVID-19 control measures on pneumonia prevention. Int J Infect Dis. 2020;96:548-9.

16. Prem K, Liu Y, Russell TW, Kucharski AJ, Eggo RM, Davies N, et al. The effect of control strategies to reduce social mixing on outcomes of the COVID-19 epidemic in Wuhan, China: a modelling study. Lancet Public Heal. 2020;5(5):e261-70.

17. Jordan V. Coronavirus (COVID-19): Infection control and prevention measures. J Prim Health Care. 2020;12(1):96-7.

18. Duan T, Jiang H, Deng X, Zhang Q, Wang F. Government intervention, risk perception, and the adoption of protective action recommendations: Evidence from the COVID-19 prevention and control experience of China. Int J Environ Res Public Health. 2020;17(10).

19. Mayr V, Ai D, Chapman A, Persad E, Klerings I, Wagner G, et al. Quarantine alone or in combination with other public health measures to control COVID-19: a rapid review. Ochr Database Syst Rev. 2020;(4):1-44.

20. Riiser K, Helseth S, Haraldstad K, Torbjørnsen A, Richardsen KR. Adolescents' health literacy, health protective measures, and health-related quality of life during the Covid-19 pandemic. PLoS One. 2020;15(8 august):1-14.

21. Chen S, Yang J, Yang W, Wang C, Bärnighausen T. COVID-19 control in China during mass population movements at New Year. Lancet. 2020;395(10226):764-6.

22. Islam N, Sharp SJ, Chowell G, Shabnam S, Kawachi I, Lacey B, et al. Physical distancing interventions and incidence of coronavirus disease 2019: Natural experiment in 149 countries. BMJ. 2020;370:1-10.

23. Cavanagh G, Wambier CG. Rational hand hygiene during the coronavirus 2019 (COVID-19) pandemic. J Am Acad Dermatol [Internet]. 2020;82(6):e211. Available from: https://doi.org/10.1016/j.jaad.2020.03.090

24. Vardoulakis S, Sheel M, Lal A, Gray D. COVID-19 environmental transmission and preventive public health measures. Aust N Z J Public Health. 2020;10-2.

25. Haque M. Handwashing in averting infectious diseases: Relevance to COVID-19. J Popul Ther Clin Pharmacol. 2020;27(Special Issues 1):e37-52.

26. European Centre for Disease Prevention and Control. Using face masks in the community Reducing COVID-19 transmission from potentially asymptomatic or pre-symptomatic people through the use of face masks [Internet]. 2020. Available from: https://www.ecdc.europa.eu/en/publications-data/using-face-masks-communityreducing-covid-19-transmission

27. Cheng KK, Lam TH, Leung CC. Wearing face masks in the community during the COVID-19 pandemic: altruism and solidarity. Lancet [Internet]. 2020;2019(20):2019-20. Available from: http://dx.doi.org/10.1016/S0140-6736(20)30918-1

28. WHO. Advice on the use of masks in the context of COVID-19. Who [Internet]. 2020;(April):1-5. Available from: https://www.who.int/publications-

29. Wilder-Smith A, Freedman DO. Isolation, quarantine, social distancing and community containment: Pivotal role for old-style public health measures in the novel coronavirus (2019-nCoV) outbreak. J Travel Med. 2020;27(2):1-4. 
30. Kwon K, H S, M S, JY K. DRIVE-THROUGH SCREENING CENTER FOR COVID-19: A SAFE AND EFFICIENT SCREENING SYSTEM AGAINST MASSIVE COMMUNITY OUTBREAK. J Korean Med Sci. 2020;(January). 